\title{
Aqueous solutions of deep eutectic systems as reaction media for the saccharification and fermentation of hardwood xylan into xylitol
}

\author{
Aloia Romaní $^{\mathrm{a}, *}$, Eduarda S. Morais ${ }^{\mathrm{b}}$, Pedro O. Soares ${ }^{\mathrm{a}}$, Mara G. Freire ${ }^{\mathrm{b}}$, Carmen S.R. Freire ${ }^{\mathrm{b}}$, \\ Armando J.D. Silvestre ${ }^{\mathrm{b}}$, Lucília Domingues ${ }^{\mathrm{a}}$ \\ ${ }^{\text {a }}$ CEB - Centre of Biological Engineering, University of Minho, Campus Gualtar, 4710-057 Braga, Portugal \\ ${ }^{\mathrm{b}}$ CICECO-Aveiro Institute of Materials and Department of Chemistry, University of Aveiro, 3810-193 Aveiro, Portugal
}

G R A P H I C A L A B S T R A C T

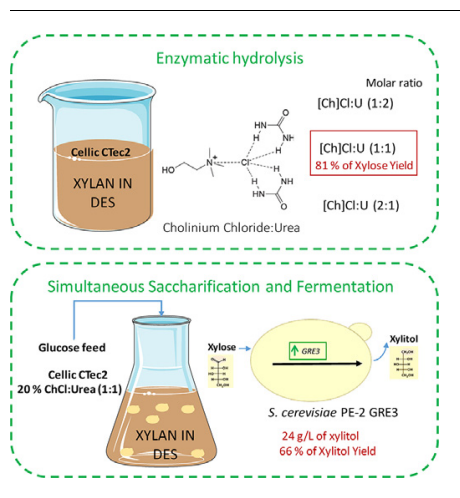

A R T I C L E I N F O

\section{Keywords:}

Xylitol

Cholinium chloride

Urea

Xylan

Simultaneous saccharification and

fermentation

\begin{abstract}
A B S T R A C T
The aim of this study was to evaluate the effect of aqueous solutions of deep eutectic solvent, Cholinium Chloride:Urea ([Ch]Cl:U) at $50 \mathrm{wt} \%$ and $20 \mathrm{wt} \%$, using different molar ratios (1:1, 2:1 and 1:2) on the enzymatic hydrolysis of xylan for xylose production and its subsequent bioconversion into xylitol using a recombinant yeast strain. The lowest xylan conversion into xylose (45\%) was obtained using 1:2 [Ch]Cl:U molar ratio. On the other hand, the $1: 1[\mathrm{Ch}] \mathrm{Cl}: \mathrm{U}$ molar ratio, at $20 \mathrm{wt} \%$ in water, improved this conversion, achieving the highest xylose yield (81.4\%). The xylitol production was then optimized with [Ch]Cl:U (1:1) at 20 wt\% by simultaneous saccharification and fermentation process, attaining $23.67 \mathrm{~g} / \mathrm{L}$, corresponding to $66.04 \%$ of xylitol yield. This study reveals the possibility of using xylan solubilized in DES aqueous solutions directly for xylitol production, thus assembling a one-step process.
\end{abstract}

\section{Introduction}

The interest in innovative strategies to support sustainable development and growth has increased tremendously in recent years. In this vein, the United Nations (UN) outlined a new sustainability-focused development plan under the title "Transforming Our World: The 2030
Agenda for Sustainable Development". This plan comprises several aspects spanning across all fields of human activities, many of them being related to the development of greener and more efficient chemical processes and their importance in sustainability (Assembly, 2015). In this context, the use of renewable feedstock and the replacement of conventional organic solvents by greener ones are two measures that

\footnotetext{
* Corresponding author.

E-mail address: aloia@ceb.uminho.pt (A. Romaní).
} 
can dramatically improve the sustainability of most chemical processes currently used in industry (Clarke et al., 2018). Simultaneously, the manufacturing of value-added products, including materials, chemicals, fuels, as well as energy from renewable resources, has emerged as an environmentally friendly and sustainable alternative to petroleum-derived products (Clark, 2007).

Within the broad scope of biorefinery, lignocellulosic feedstocks are the most promising biomass sources for chemical manufacturing (Werpy et al., 2004) and their production rate is approximately $200 \times 10^{9}$ tons per year. Among lignocellulosic materials, fast-growing and short-rotation hardwoods (such as eucalyptus and beech) have great importance due to their high biomass yield per hectare, which makes them extremely attractive as energy crops. Besides, these are widespread raw materials used in the cellulose pulp mill (Romaní et al., 2019). Hardwood cell wall, that accounts for about $90 \%$ of its dry weight (Kumar et al., 2009), is composed by approximately $44 \%$ of cellulose, $20 \%$ of hemicellulose (mainly xylan) and $27 \%$ of lignin (Romaní et al., 2010). In a biorefinery context, cellulose is the fraction most used for biofuels production such as ethanol. Nevertheless, their implementation on large-scale is still not economically viable. To overcome this limitation, the production of high-value products from hemicellulose (such as xylitol) coupled to biofuels is vital to improve the feasibility of lignocellulosic biorefinery (Budzianowski, 2017). On the other hand, due to the recalcitrant nature of biomass, polysaccharides conversion into monosaccharides by enzymatic hydrolysis, a key step in the conversion into value-added products, is often hampered (Romaní et al., 2010). Therefore, a pretreatment step, involving biomass fractionation into major components, is normally required (Domínguez et al., 2017). In this context, the selection of efficient processes for the biomass fractionation is determinant for the economic viability and sustainability of biorefinery processes (Soh and Eckelman, 2016).

Deep eutectic solvents (DES) are a new class of alternative solvents, initially proposed by Abbott et al. (2003), prepared combining hydrogen bond donors (HBDs) and hydrogen bond acceptors (HBAs) thus forming eutectic mixtures with a melting point lower than those of the starting components. DES present several advantages over conventional imidazolium-based ionic liquids (ILs); notably, they are frequently of lower-cost and easier to prepare while having physicochemical properties comparable to ILs (Clarke et al., 2018; Loow et al., 2017). Furthermore, they present similar "designer solvent" characteristics (Zhang et al., 2012) given the large variety of HBAs and HBDs that can be used and respective proportions. Over the last few years, the use of DES as greener alternatives to conventional solvents for lignocellulosic biomass processing has attracted increased attention, in areas spanning from delignification (Shen et al., 2019; Soares et al., 2017; Alvarez-Vasco et al., 2016) to high value compounds extraction (Gullón et al., 2019) and their conversion into added value products (Morais et al., 2020).

Recently, aqueous solutions of eutectic mixtures composed of cholinium chloride and urea ([Ch]Cl:U) have been used for the extraction of xylan from Eucalyptus globulus wood (Morais et al., 2018). Among many other relevant applications (Zhang et al., 2014), xylan can be used as a starting material for the production of xylitol, used as sweetener in food and pharmaceutical industries (Baptista et al., 2018, 2020). However, in most cases, an intermediate step of hydrolysis of xylan into xylose is required (Yemiş and Mazza, 2011), often achieved by chemical and enzymatic approaches (Latif and Rajoka, 2001). However, the enzymes and microorganisms required for biomass processing could be affected by DES presence, and therefore the evaluation of their effect is a critical point (Satlewal et al., 2018). Some studies have evaluated the stability of cellulases in the presence of DES and their effect on the enzymatic saccharification of cellulose (Gunny et al., 2015; Guo et al., 2018; Shen et al., 2019). Nevertheless, to the best of our knowledge, there are no previous studies about xylan saccharification and microbial conversion into value-added compounds in these solvents.
In here, an integrated strategy for the simultaneous saccharification and bioconversion of xylan has been developed for the biotechnological production of xylitol from corncob whole slurry using a Saccharomyces cerevisiae PE2 strain overexpressing the GRE3 gene (codifying for an unspecific aldose reductase responsible for the conversion of xylose into xylitol), (Baptista et al., 2018).

Specifically, the aim of this work was to evaluate the enzymatic hydrolysis of solubilized xylan in [Ch]Cl: $\mathrm{U}$ aqueous solutions at different molar ratios (1:2, 2:1 and 1:1), and concentrations (50 and $20 \mathrm{wt}$ $\%$, respectively) and of recovered xylan after DES solubilization. A onepot process was developed by the optimization (studied variables: xylan ( $w t \%)$, glucose ( $\mathrm{g} / \mathrm{L}$ ) and enzyme loading $(\mathrm{g} / \mathrm{L})$ ) of the simultaneous saccharification and fermentation (SSF) for the bioconversion of xylan into xylitol, with the ultimate goal of lignocellulosic biomass valorization using sustainable processes.

\section{Material and methods}

\subsection{Materials}

Cholinium Chloride ([Ch]Cl) (Sigma, USA, 99\% purity) was used as HBA and Urea (U) (Sigma, USA, $\geq 99 \%$ purity) was used as HBD for the DES preparation. Xylan from beechwood, obtained from Apollo Scientific ( $\geq 90 \%$ ), was used as model compound for the solubility and bioconversion assays. YPD medium (composed by $10 \mathrm{~g} / \mathrm{L}$ yeast extract (Liofilchem, Abruzzi, Italy), $20 \mathrm{~g} / \mathrm{L}$ peptone (Biokar diagnostics, Beauvais, France) and $20 \mathrm{~g} / \mathrm{L}$ glucose (Biochem Chemopharma, Cosne sur loire, France)) supplemented with $150 \mathrm{mg} / \mathrm{L}$ of geneticin (G418, Sigma-Aldrich, St. Louis, MO, USA) was used for yeast growth. Glucose (Biochem Chemopharma, Cosne sur loire, France, $\geq 99 \%$ purity), ethanol (AppliChem, Darmstadt, Germany, $\geq 99 \%$ purity), xylose (AppliChem, Darmstadt, Germany AppliChem, Darmstadt) and xylitol (Sigma-Aldrich, St. Louis, MO, USA AppliChem, Darmstadt) were used as standards in HPLC analysis and $0.005 \mathrm{M}$ sulfuric acid (Biochem Chemopharma, Cosne sur loire, France) was used as eluent.

\subsection{Methods}

\subsubsection{Preparation of DES and xylan solutions in aqueous DES}

Before DES preparation, the humidity of its precursors (cholinium chloride and urea) was measured with a Metrohm 831 Karl Fisher coulometer, with a maximum of water determined of $5.21 \mathrm{wt} \%$. [Ch]Cl and $U$ were accurately weighted and placed in sealed glass vials, and the heated under constant stirring until a transparent liquid was formed, in order to prepare DES with 2:1, 1:1 and 1:2 M ratios. After liquid formation, the mixture was kept at this temperature for one hour before being allowed to return to room temperature. DES composition and stability was confirmed by ${ }^{1} \mathrm{H}$ NMR and ${ }^{13} \mathrm{C}$ NMR analysis, using a Bruker Avance 300 at $300.13 \mathrm{MHz}$ and $75.47 \mathrm{MHz}$, respectively, deuterated water as solvent and trimethylsilyl propanoic acid (TMSP) as internal reference, as reported elsewhere (Morais et al., 2018).

For the preparation of the xylan solutions, appropriated amounts of xylan were solubilized in 20 and $50 \mathrm{wt} \%$ DES aqueous solutions up to a xylan concentration of 100 and $150 \mathrm{~g} / \mathrm{L}$, as shown in Table 1 . These concentrations were selected taking into consideration our previous

Table 1

Cholinium Chloride:Urea ([Ch]Cl:U) DES ratios and dilutions, as well as xylan concentrations used in the present study.

\begin{tabular}{lll}
\hline $\begin{array}{l}\text { Molar ratios } \\
\text { (HBA:HBD) }\end{array}$ & $\begin{array}{l}\text { DES ([Ch]Cl:U) content } \\
\text { water (wt.\%) }\end{array}$ & Xylan Concentration $(\mathrm{g} / \mathrm{L})$ \\
\hline $1: 2$ & 50 & 150 \\
$1: 2$ & 20 & 100 \\
$1: 1$ & 20 & 100 \\
$2: 1$ & 20 & 100 \\
\hline
\end{tabular}


studies on the solubility of xylan in [Ch]Cl:U aqueous solutions (Morais et al., 2018). The $\mathrm{pH}$ of $\mathrm{DES}$ aqueous solutions was measured at $25.0 \pm 0.01{ }^{\circ} \mathrm{C}$ using a Metrohm $827 \mathrm{pH}$ meter, with an uncertainty of \pm 0.01 . The density of the aqueous solutions was also measured at atmospheric pressure, and in the temperature range from 0 to $30{ }^{\circ} \mathrm{C}$, using an automated SVM 3000 Anton Paar rotational Stabinger viscometer-densimeter (temperature uncertainty: $\pm 0.02 \mathrm{~K}$; absolute density uncertainty: $\left.\pm 5 \times 10^{-4} \mathrm{~g} / \mathrm{cm}^{3}\right)$.

\subsubsection{Xylan precipitation and recovery}

Xylan was recovered from DES aqueous solutions to evaluate DES effect in the enzymatic saccharification. Xylan was precipitated by adding the same weight of absolute ethanol to the DES solution and left under stirring at $800 \mathrm{rpm}$ for $24 \mathrm{~h}$. The recovered solid was then vacuum filtrated using nylon Whatman $0.45 \mu \mathrm{m}$ pore filters. After that, the precipitated material was washed with ethanol and acetone. The recovered xylan was then put in a $40{ }^{\circ} \mathrm{C}$ ventilated oven overnight and weighted. The pristine and recovered xylan have been analyzed by NMR, matrix-assisted laser desorption ionization time-of-flight mass spectrometry (Maldi-ToF-MS) and size exclusion chromatography (SEC) as described elsewhere (Morais et al., 2018).

\subsubsection{Enzymatic hydrolysis of xylan}

Solubilized xylan in DES aqueous solutions, precipitated xylan from DES solution and pristine beechwood xylan samples were diluted/solubilized with $50 \mathrm{mmol} / \mathrm{L}$ citrate buffer (to reach a final xylan concentration of 100, 50 and $20 \mathrm{~g} / \mathrm{L}$ ) and used as substrates in enzymatic hydrolysis assays (Table 2) using commercial enzymes (CellicTec2, kindly supplied by Novozymes) at an enzyme loading of $4800 \mathrm{UI} / \mathrm{g}$ xylan. All assays were conducted in duplicate.

Xylanase activity was measured following the procedure previously described (Bailey et al., 1992) and was found to be $9764 \mathrm{UI} / \mathrm{mL}$ (expressed as $\mu \mathrm{mol} / \mathrm{mL} \cdot \mathrm{min}$ ), corresponding to $69 \mathrm{mg}$ of protein $/ \mathrm{mL}$ quantified by Bradford method (Bradford, 1976). Enzymatic experiments were carried out in an orbital shaker incubator at $50{ }^{\circ} \mathrm{C}$ and $150 \mathrm{rpm}$. The $\mathrm{pH}$ was adjusted to $4.8-5$ with aqueous $\mathrm{NaOH} 4 \mathrm{~mol} / \mathrm{L}$. Aliquots of the reaction media were withdrawn at desired times and analyzed by HPLC (JASCO), using a BioRad HPX-87H $(300 \times 7.8 \mathrm{~mm})$ column, at $60{ }^{\circ} \mathrm{C}$ with $0.005 \mathrm{M}$ aqueous sulfuric acid as eluent in a flow rate of $0.6 \mathrm{~mL} / \mathrm{min}$ and a Knauer-IR refractive index detector. The yield of enzymatic saccharification of xylan was determined by the following equation.

XyloseYield $=\frac{\text { xyloseconcentration }}{\text { xylanconcentration }} \cdot 100 \%$

\subsubsection{Microorganism and inoculum preparation}

The yeast strain used in this work was Saccharomyces cerevisiae PE-2 GRE3 (constructed in Baptista et al., 2018). The stock cultures were maintained on YPD agar ( $2 \%$ of glucose, $2 \%$ of agar, $1 \%$ of yeast extract and $2 \%$ of peptone) containing $200 \mathrm{mg} / \mathrm{L}$ of geneticin (G418) at $4{ }^{\circ} \mathrm{C}$. For the inoculum, cells were grown in YPD liquid medium with $150 \mathrm{mg} / \mathrm{L}$ of G418 for $15 \mathrm{~h}$ at $30^{\circ} \mathrm{C}$. Cell suspensions were recovered by centrifugation ( $5 \mathrm{~min}$ at $3000 \mathrm{rpm}, 4{ }^{\circ} \mathrm{C}$ ) and suspended in $0.9 \%$ of $\mathrm{NaCl}$. The Simultaneous Saccharification and Fermentation (SSF) assays were inoculated with $11 \mathrm{~g}$ fresh yeast/L (corresponding to $5 \mathrm{~g} / \mathrm{L}$ of dry yeast/L).

2.2.5. Simultaneous saccharification and fermentation for xylitol production: Box-Behnken design

The SSF experiments were carried out in $50 \mathrm{~mL}$ Erlenmeyer flasks placed in an orbital shaker at $35{ }^{\circ} \mathrm{C}$ and $150 \mathrm{rpm}$. The $\mathrm{pH}$ of culture media was adjusted to 5 with aqueous solution of $\mathrm{NaOH}(4 \mathrm{~mol} / \mathrm{L})$ or $\mathrm{HCl}(1 \mathrm{~mol} / \mathrm{L})$. Nutrients $(10 \mathrm{~g} / \mathrm{L}$ of yeast extract and $20 \mathrm{~g} / \mathrm{L}$ of peptone), solubilized xylan and glucose concentrate solution were sterilized separately by autoclave $\left(121{ }^{\circ} \mathrm{C}, 20 \mathrm{~min}\right)$ prior to fermentation trials. Then, solubilized xylan was mixed with glucose, water and enzymes needed to achieve the conditions used in this work (as shown in Table 3).

A Box-Behnken experimental design with three replicates at the central point (total: 15 experiments) was carried out for the optimization of xylitol production by SSF process. The independent variables studied were: glucose concentration $(20-60 \mathrm{~g} / \mathrm{L})$, necessary for yeast growth and metabolism, concentration of xylan (10-80 g/L) solubilized in $[\mathrm{Ch}] \mathrm{Cl}: \mathrm{U}$ aqueous solution (corresponding to concentration of $2-16 \mathrm{wt} \%)$ and enzymes loadings $(0.38-0.77 \mathrm{mg} / \mathrm{mL})$ to allow the saccharification of xylan into xylose, used as substrate for xylitol bioconversion.

Aliquots were withdrawn at desired times and analyzed by HPLC. Xylitol yield was calculated using the following equation:

XylitolYield $=\frac{\text { xylitolconcentration }}{\text { xylanconcentration }} \cdot 100 \%$

The experimental data were fitted to the following equation using a commercial software (Microsoft Excel by Microsoft, USA).

$y_{j}=b_{0 j}+\sum_{i=1}^{2} b_{i j} x_{i}+\sum_{i=1}^{2} \sum_{k \geqslant i}^{2} b_{i k j} x_{i} x_{k}$

where yj ( $\mathrm{j}=1$ to 3 ) is the dependent variable; $x i$ or $x k$ ( $i$ or $k$ : 1 to 3 , $\mathrm{k} \geq \mathrm{i}$ ) are the dimensionless, normalized, independent variables (glucose concentration, xylan concentration and enzyme loading), and $\mathrm{b}_{0 \mathrm{j}} \ldots$

Table 2

Enzymatic hydrolysis of solubilized xylan in 20\% [Ch]Cl:U (1:2, 1:1 and 2:1 M ratio) and precipitated xylan from 20\% [Ch]Cl:U (2:1) and pristine xylan.

\begin{tabular}{|c|c|c|c|c|}
\hline \multicolumn{3}{|l|}{ Operational conditions of enzymatic hydrolysis } & \multicolumn{2}{|c|}{ Main results calculated at $96 \mathrm{~h}$} \\
\hline Substrate & Xylan concentration (g/L) & [Ch]Cl:U (wt. \%) & Xylose concentration $(\mathrm{g} / \mathrm{L})$ & Xylose yield ( $\mathrm{g}$ xylose $/ 100 \mathrm{~g}$ of xylan) \\
\hline \multirow[t]{3}{*}{ Pristine xylan (as control) } & 100 & - & $70.4 \pm 0.03$ & $70.5 \pm 0.03$ \\
\hline & 50 & - & $37.7 \pm 0.32$ & $74.7 \pm 0.64$ \\
\hline & 20 & - & $16.0 \pm 0.52$ & $79.9 \pm 0.19$ \\
\hline \multirow[t]{3}{*}{ Precipitated xylan from $[\mathrm{Ch}] \mathrm{Cl}: \mathrm{U}$ (molar ratio $2: 1$ ) } & 100 & - & $69.6 \pm 0.62$ & $69.6 \pm 0.78$ \\
\hline & 50 & - & $36.5 \pm 1.6$ & $72.9 \pm 1.2$ \\
\hline & 20 & - & $17.6 \pm 0.89$ & $87.8 \pm 0.56$ \\
\hline \multirow[t]{3}{*}{ Solubilized xylan in [Ch]Cl:U(molar ratio $2: 1$ ) } & 100 & 20 & $52.0 \pm 0.67$ & $52.0 \pm 0.32$ \\
\hline & 50 & 10 & $30.3 \pm 1.0$ & $60.7 \pm 0.79$ \\
\hline & 20 & 4 & $15.8 \pm 0.78$ & $78.9 \pm 0.48$ \\
\hline \multirow[t]{3}{*}{ Solubilized xylan in [Ch]Cl:U(molar ratio 1:2) } & 100 & 20 & $34.9 \pm 1.3$ & $34.9 \pm 0.92$ \\
\hline & 50 & 10 & $24.9 \pm 0.56$ & $49.8 \pm 0.43$ \\
\hline & 20 & 4 & $11.9 \pm 0.78$ & $59.6 \pm 0.31$ \\
\hline \multirow[t]{3}{*}{ Solubilized xylan in [Ch]Cl:U(molar ratio $1: 1$ ) } & 100 & 20 & $54.9 \pm 0.81$ & $54.9 \pm 0.96$ \\
\hline & 50 & 10 & $38.0 \pm 0.45$ & $76.0 \pm 0.42$ \\
\hline & 20 & 4 & $16.3 \pm 0.32$ & $81.5 \pm 1.5$ \\
\hline
\end{tabular}


Table 3

Operational conditions expressed in terms of dimensionless and dimension independent variables.

\begin{tabular}{lllll}
\hline & $\begin{array}{l}\text { Glucose } \\
\text { concentration }(\mathrm{g} /\end{array}$ & $\begin{array}{l}{[\mathrm{Ch}] \mathrm{Cl}: \mathrm{U}} \\
(1: 1 \mathrm{M} \text { ratio) } \\
\text { Lt. } \%\end{array}$ & $\begin{array}{l}\text { Xylan } \\
\text { concentration }(\mathrm{g})\end{array}$ & $\begin{array}{l}\text { Enzyme } \\
\text { L) (x2) } \\
\text { loading (mg } \\
\text { protein/mL) } \\
(\mathrm{x} 3)\end{array}$ \\
\hline run 1 & $40(0)$ & 2 & $10(-1)$ & $0.38(-1)$ \\
run 2 & $60(1)$ & 2 & $10(-1)$ & $0.58(0)$ \\
run 3 & $60(1)$ & 9 & $45(0)$ & $0.38(-1)$ \\
run 4 & $40(0)$ & 9 & $45(0)$ & $0.58(0)$ \\
run 5 & $60(1)$ & 16 & $80(1)$ & $0.58(0)$ \\
run 6 & $20(-1)$ & 9 & $45(0)$ & $0.77(1)$ \\
run 7 & $40(0)$ & 9 & $45(0)$ & $0.58(0)$ \\
run 8 & $20(-1)$ & 16 & $80(1)$ & $0.58(0)$ \\
run 9 & $20(-1)$ & 2 & $10(-1)$ & $0.58(0)$ \\
run 10 & $40(0)$ & 16 & $80(1)$ & $0.77(1)$ \\
run 11 & $40(0)$ & 16 & $80(1)$ & $0.38(-1)$ \\
run 12 & $40(0)$ & 2 & $10(-1)$ & $0.77(1)$ \\
run 13 & $20(-1)$ & 9 & $45(0)$ & $0.38(-1)$ \\
run 14 & $40(0)$ & 9 & $45(0)$ & $0.58(0)$ \\
run 15 & $60(1)$ & 9 & $45(0)$ & $0.77(1)$ \\
\hline
\end{tabular}

$b_{i k j}$ are regression coefficients calculated from experimental data by multiple regression using the least-squares method.

\section{Results and discussion}

\subsection{Preliminary evaluation of [Ch]Cl:U effect on enzymatic hydrolysis of} xylan and yeast glucose consumption

Xylitol production from lignocellulosic biomass can be achieved through the two following processes: i) enzymatic saccharification of xylan into xylose (xylan may hydrolysed into xylooliogosaccharides by endoxylanase, which can be cleaved into xylose by xylosidase) and ii) subsequent bioconversion of xylose into xylitol by recombinant yeast, overexpressing the GRE3 gene that codifies an unspecific aldose reductase using NADPH as co-factor able to convert xylose into xylitol (Baptista et al., 2018). With the goal of attaining insights about the DES effect on enzymes and yeast strain performance, enzymatic hydrolysis and fermentation assays were initially carried out in the presence of [Ch]Cl:U aqueous solution (1:2 M ratio). Based on previous results, and knowing that $50 \mathrm{wt} \%$ of [Ch]Cl:U (1:2) can solubilize up to $321 \mathrm{~g} / \mathrm{L}$ of beechwood xylan (Morais et al., 2018), $150 \mathrm{~g} / \mathrm{L}$ of xylan were diluted with $50 \mathrm{mmol} / \mathrm{L}$ of citrate buffer achieving a xylan concentration of $100 \mathrm{~g} / \mathrm{L}, 50$ and $20 \mathrm{~g} / \mathrm{L}$ (corresponding to 33, 17 and $7 \mathrm{wt} \%$ of [Ch]Cl:U, respectively).

The effect of the different DES solutions during enzymatic hydrolysis $(120 \mathrm{~h})$ is shown in Fig. 1a. The highest xylose yield $(47.9 \% \pm 0.73)$ was achieved with a xylan concentration of $20 \mathrm{~g} / \mathrm{L}$ (7 wt\% DES). Nonetheless, this yield is similar to the maximum yield $(45.1 \% \pm 0.16)$ attained with $50 \mathrm{~g} / \mathrm{L}$ of xylan, revealing a not significant decrease in yield with the increase in DES concentration. The inhibitory effect of DES components such as urea has been previously reported (Attri et al., 2011). Urea can cause the unfolding of enzymes leading to its inactivation (Durand et al., 2014), as it is a chaotropic agent that denatures proteins by breaking protein hydrogen bonds and by interacting preferentially with the protein surface (Attri et al., 2011). Despite xylose yields are lower than $50 \%$ in these assays, the enzyme cocktail was able to maintain the activity at least for the first $24 \mathrm{~h}$ of xylan saccharification (Fig. 1a), showing that this approach could be used in the next steps.

Yeast performance was also evaluated in the same conditions as the ones used for the enzymatic hydrolysis, using [Ch]Cl:U (1:2) in the following DES concentrations: 33, 17 and $7 \%$ wt. The samples were prepared and inoculated with $11 \mathrm{~g}$ fresh yeast biomass/L and the results of the assays are summarized in Fig. 1b. Glucose consumption by the a)

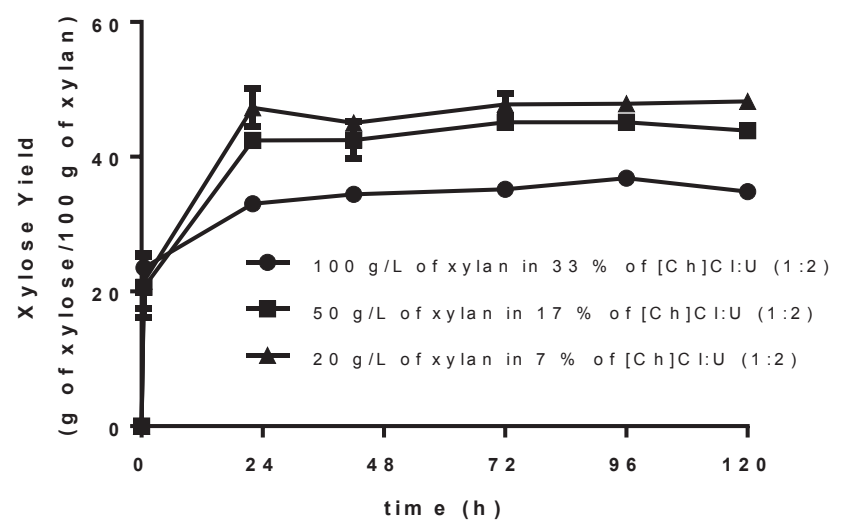

b)

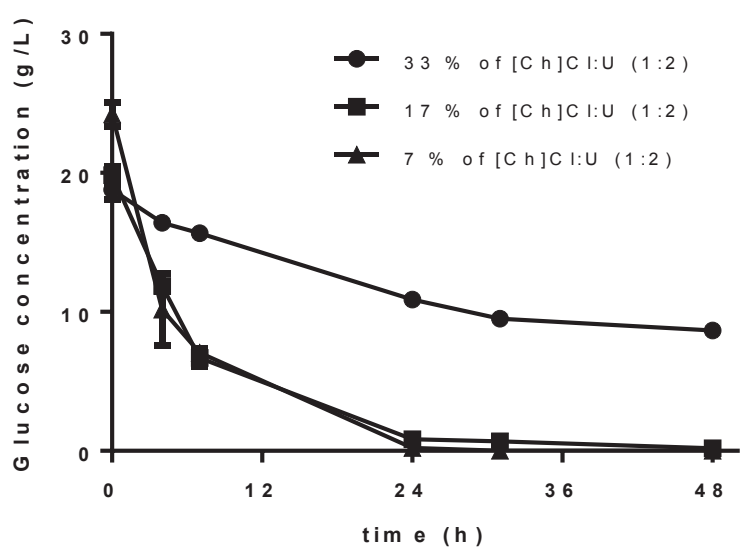

Fig. 1. Preliminary assays using 33,17 and $7 \%$ wt. of $[\mathrm{Ch}] \mathrm{Cl}: \mathrm{U}(1: 2 \mathrm{M}$ ratio) to evaluate their effect on: a) Enzymatic hydrolysis of 100, 50 and $20 \mathrm{~g} / \mathrm{L}$ of solubilized xylan and b) $20 \mathrm{~g} / \mathrm{L}$ of glucose consumption by Saccharomyces cerevisiae PE2 GRE3 yeast strain.

yeast at the lowest DES concentrations (17 and $7 \mathrm{wt} \%$ ) was similar, achieving glucose depletion in the first $24 \mathrm{~h}$ of fermentation. On the other hand, glucose was not completely consumed in the presence of $33 \mathrm{wt} \%$ of $[\mathrm{Ch}] \mathrm{Cl}: \mathrm{U}$, which suggests a negative influence in the yeast performance for this condition. Hence, the results attained for the enzymatic and yeast performance in the different [Ch]Cl:U concentrations highlight that DES aqueous solutions can be used for enzymatic hydrolysis and fermentation at concentrations below $33 \mathrm{wt} \%$.

\subsection{Enhancement of enzymatic hydrolysis of xylan using $20 \mathrm{wt} \%$ of [Ch]Cl:U aqueous solution}

Although promising results were attained during the preliminary assays on enzymatic hydrolysis, it was revealed that high DES concentrations have a negative effect on the enzyme activity. Nevertheless, $[\mathrm{Ch}] \mathrm{Cl}: \mathrm{U}$ displays a very high capability of solubilizing xylan, even at lower DES concentrations (Morais et al., 2018). Due to this solvent characteristic it is possible to have a high concentration of xylan in diluted aqueous DES solutions, which may have lower impact in the enzymatic hydrolysis process. Taking this in mind, solutions with $100 \mathrm{~g} / \mathrm{L}$ of xylan in $20 \mathrm{wt} \%$ of DES were prepared. Moreover, and due to the possible negative effect of urea in the process, different ratios of [Ch]Cl:U were tested (Table 1), specifically (1:1), (1:2) and (2:1), and its effect was further evaluated on the enzymatic hydrolysis of xylan and on the corresponding xylose yields. These solutions were then diluted to obtain 50 and $20 \mathrm{~g} / \mathrm{L}$ of xylan to evaluate the effect of the substrate concentration, percentage of $[\mathrm{Ch}] \mathrm{Cl}: \mathrm{U}$ (corresponding to 10 
a)



b)



c)



Fig. 2. Enzymatic hydrolysis of solubilized xylan in $20 \%$ of $[\mathrm{Ch}] \mathrm{Cl}: \mathrm{U}$ at: a) molar ratio of 2:1; b) molar ratio of 1:1 and c) molar ratio 1:2.

and $4 \mathrm{wt} \%$ ), and molar ratio on enzymatic hydrolysis. As control, pristine xylan (without solubilization in DES) was mixed with $50 \mathrm{mmol} / \mathrm{L}$ citrate buffer to achieve the same concentrations (100, 50 and $20 \mathrm{~g} / \mathrm{L}$ of xylan). Additionally, solubilized xylan in $20 \mathrm{wt} \%$ of [Ch]Cl:U aqueous solution (2:1 M ratio) was precipitated with absolute ethanol and was also used as substrate in enzymatic hydrolysis assays to compare with not solubilized prisitine xylan and ascertain if the DES effect in xylan structure could be beneficial for xylitol production.

Table 2 collects the operational conditions (substrates used and their concentrations) of enzymatic hydrolysis assays and the main results obtained, viz xylose concentration and xylose yield at 96 h. Fig. 2 shows the time course of the enzymatic hydrolysis of solubilized xylan at different molar ratios of [Ch]Cl:U (results expressed as xylose yield). It is observed that the highest xylose yields were obtained using $20 \mathrm{~g} / \mathrm{L}$ of solubilized xylan for all molar ratios tested. Nevertheless, improvements of 36 and $32 \%$ in xylose yields were achieved using [Ch]Cl:U 1:1 and 2:1 $\mathrm{M}$ ratios, respectively, when compared to results obtained with 1:2 $\mathrm{M}$ ratio (Table 2 and Fig. 2). These results show that the molar ratio of 1:1 has the best results on xylose yields and it was thus chosen to be used in the final stage of the process optimization.

As seen in Table 2, the highest value of xylose concentration (54 g/ $\mathrm{L}$ ), in presence of DES, was achieved using $100 \mathrm{~g} / \mathrm{L}$ of xylan in $20 \mathrm{wt} \%$ 


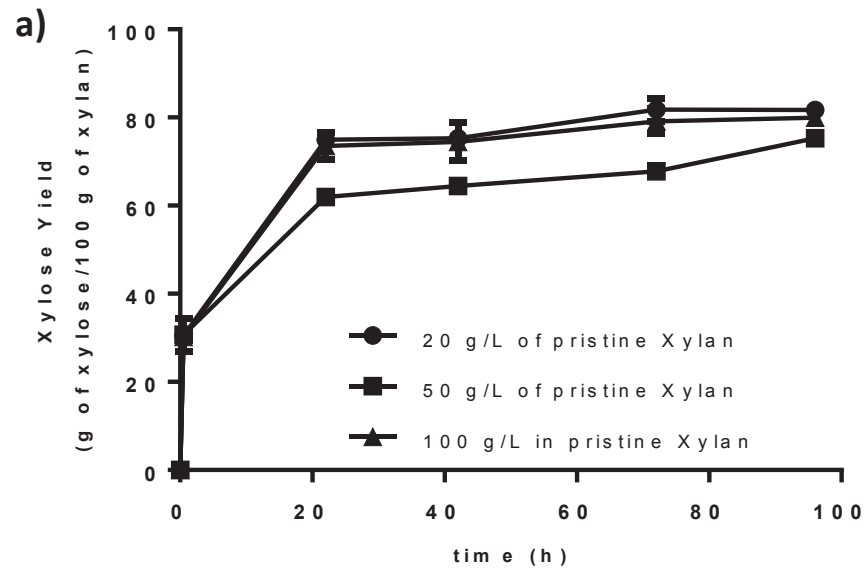

b)

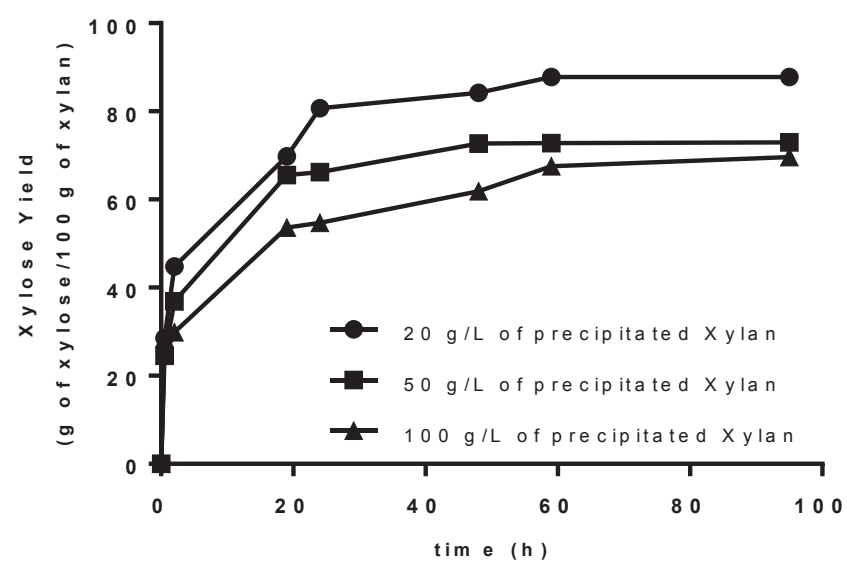

Fig. 3. Enzymatic hydrolysis of: a) precipitated xylan from $20 \%$ wt. of [Ch]Cl:U (1:2 M ratio) and, b) pristine xylan.

of [Ch]Cl:U (1:1), corresponding to a xylose yield of 54\%. However, the aqueous solution of $20 \mathrm{~g} / \mathrm{L}$ of xylan in $4 \mathrm{wt} \%$ of DES (1:1) attained a xylose yield of $81.5 \%$, more than $40 \%$ increase in yield when compared with the undiluted DES (Table 2). These results can be positively compared with those reported in literature, in which corncob was pretreated with [Ch]Cl:U 1:2 M ratio at $80{ }^{\circ} \mathrm{C}$ and $115{ }^{\circ} \mathrm{C}$ for $15 \mathrm{~h}$ and the pretreated biomass was enzymatically saccharified obtaining 22.9 and $31.9 \%$ of xylose yield, respectively (Procentese et al., 2015).

Particularly with DES aqueous solutions of $7 \mathrm{wt} \%(2: 1)$ and $4 \mathrm{wt} \%$ (1:1) (Fig. 2a and b), xylose yields were only slightly lower than the yields obtained with pristine xylan in citrate buffer as reaction media (Fig. 3a) and precipitated xylan from DES aqueous solution (Fig. 3b). Therefore, the enzymatic hydrolysis of xylan is not significantly hampered using these DES concentrations and molar ratios.

On the other hand, the results of enzymatic hydrolysis shown in Fig. 3b reveal an improvement of $9.8 \%$ in the xylan saccharification when comparing the pristine xylan with the precipitated xylan from the DES media. These results suggest a positive effect of the [Ch]Cl:U dissolution process over the saccharification of the polysaccharide, which might be related with the structural changes undergone during the process, namely the complete removal of 4-O-methyl- $\alpha$-D-GlpcA units as demonstrated by ${ }^{1} \mathrm{H}$ and ${ }^{13} \mathrm{C}$ NMR and MALDI-TOF-MS, structural analyses previously reported (Morais et al., 2018). These results highlight that DES can also be used in the pretreatment of xylan, making them more accessible for enzymatic saccharification into xylose or others. Nevertheless, to avoid costly separation stages and with the goal of achieving a one-pot process, xylan solubilized in $20 \mathrm{wt} \%$ of $[\mathrm{Ch}] \mathrm{Cl}: \mathrm{U}$ molar ratio 1:1 was selected for the integrated xylitol production.

\subsection{Simultaneous saccharification and fermentation for xylitol production}

In this work, an innovative process is proposed for the biological production of xylitol from xylan by simultaneous saccharification and fermentation (SSF). The xylan is hydrolyzed by enzymes, for xylose production, while simultaneously the recombinant yeast converts the released xylose into xylitol. S. cerevisiae PE-2 GRE3, the recombinant strain used in the SSF assays, is an industrial strain isolated from first generation bioethanol plant engineered to accumulate xylitol by overexpressing the endogenous unspecific aldose reductase GRE3 that converts xylose to xylitol (Baptista et al., 2018).

According to the optimization performed in the initial assays of this work, $20 \mathrm{~g} / \mathrm{L}$ of xylan in $20 \mathrm{wt} \%$ of [Ch]Cl:U (1:1) were used to perform the SSF assays displayed in Fig. 5. The results are displayed as the time course of xylitol produced by these SSF assays (expressed as xylitol yield). Significant differences among assays occur in xylitol production (Fig. 4) depending on the conditions used (Table 3).

Results regarding glucose consumption, ethanol produced and nonconsumed xylose are included in Table 4. Glucose was almost completely consumed after $20 \mathrm{~h}$ of SSF, except for runs 5 and 11, that had final concentrations of glucose of 14.8 and $20.8 \mathrm{~g} / \mathrm{L}$ (at $30 \mathrm{~h}$ ), respectively. Ethanol concentration varied in the range of 2.8-28 g/L (run 13 and 2, respectively). Maximum ethanol concentration (28 g/L) was achieved using $60 \mathrm{~g} / \mathrm{L}$ of glucose in presence of the lowest concentration of [Ch]Cl:U (2 $\mathrm{wt} \%)$. After glucose depletion, ethanol was used as carbon source achieving ethanol concentrations lower than $9 \mathrm{~g} / \mathrm{L}$ at $120 \mathrm{~h}$ in all SSF assays (Table 4).

The results obtained reveal that the fermentation performance is not affected by the presence of DES in the media. This trend is contrary to a previous study in which $5 \mathrm{wt} \%$ DES, namely [Ch]Cl:U (1:2) and [Ch]Cl:glycerol (1:2), were used with the laboratory strain $S$. cerevisiae BY4741 and [Ch]Cl:U (1:2) displayed a inhibitory effect (Xu et al., 2018). These differences could result from differences on the robustness of laboratory and industrial strains as the robust chassis of industrial strain PE-2 evaluated in the present study, revealed higher capacity of fermentation in presence of inhibitory compounds derived from lignocellulosic pre-treatment (Pereira et al., 2014; Cunha et al., 2019). These results show the relevance of testing green solvents applicability close to process-like conditions, namely with the process yeast strain (Costa et al., 2017).

Finally, and when evaluating xylitol production, maximum xylose bioconversion into xylitol was achieved at $72 \mathrm{~h}$ of fermentation in almost all studied conditions. The highest xylitol concentration $(25.40 \mathrm{~g} /$ L) was achieved at the end of the fermentation $(120 \mathrm{~h})$ with $20 \mathrm{~g} / \mathrm{L}$ of initial glucose, $45 \mathrm{~g} / \mathrm{L}$ of xylan in $9 \mathrm{wt} \%$ of DES solution and $0.77 \mathrm{mg} /$ $\mathrm{ml}$ of enzyme (run 6), which translates into a yield of $56.44 \mathrm{~g}$ xylitol/ $100 \mathrm{~g}$ xylan. On the other hand, the highest yield (76.15 $\mathrm{g}$ xylitol/100 $\mathrm{g}$ xylan) was obtained with $60 \mathrm{~g} / \mathrm{L}$ glucose, and with the lowest substrate concentration (10 g/L of xylan in $2 \mathrm{wt} \%$ of $[\mathrm{Ch}] \mathrm{Cl}: \mathrm{U}$ aqueous solution) and $0.58 \mathrm{mg} / \mathrm{ml}$ of enzyme (run 2).

The lowest xylitol production (4.62 g/L) and yield (5.77 g xylitol/ $100 \mathrm{~g}$ xylan) were achieved with $40 \mathrm{~g} / \mathrm{L}, 80 \mathrm{~g} / \mathrm{L}$ of xylan in $16 \mathrm{wt} \%$ of [Ch]Cl:U aqueous solution and $0.38 \mathrm{mg} / \mathrm{mL}$ of enzyme (run 11). These results are directly related to the enzyme sensitivity to DES (16 wt \%), since xylose concentration at the end of SSF varied in the range 17.1-20.7 $\mathrm{g} / \mathrm{L}$ for the assays using $80 \mathrm{~g} / \mathrm{L}$ of xylan in $16 \mathrm{wt} \%$ of [Ch]Cl:U.

\subsection{Response surface methodology assessment for optimization of xylitol production}

For an optimization of the conditions for the SSF assays, response surface was used. The independent variables (glucose concentration, xylan concentration and enzyme loadings) collected in Table 3 were correlated with dependent variables (xylitol concentration, xylitol yield and xylitol productivity at $48 \mathrm{~h}$, shown in Table 4) following the 
a)

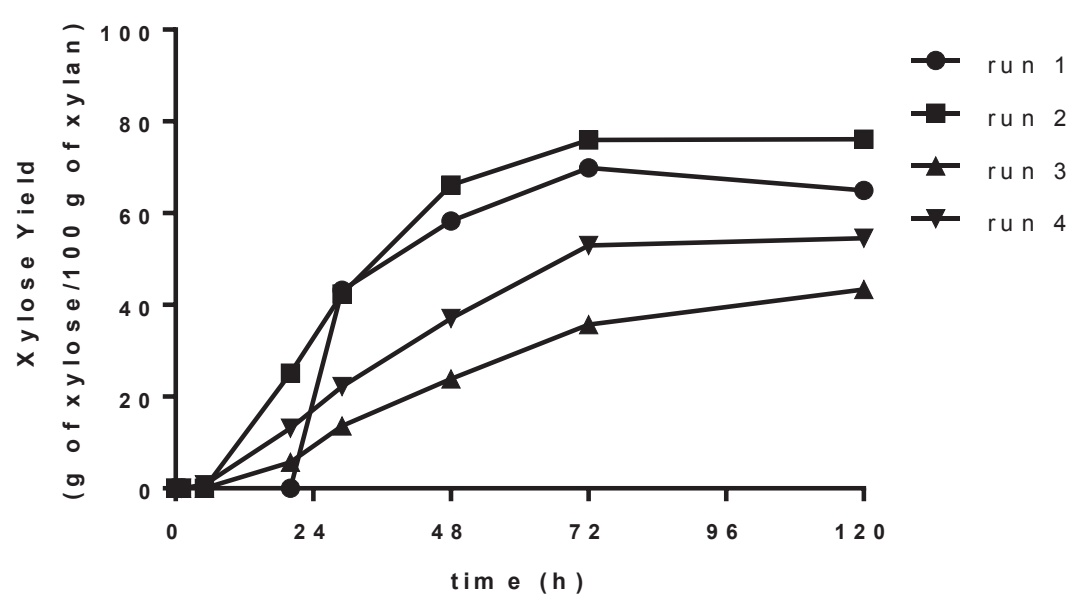

b)

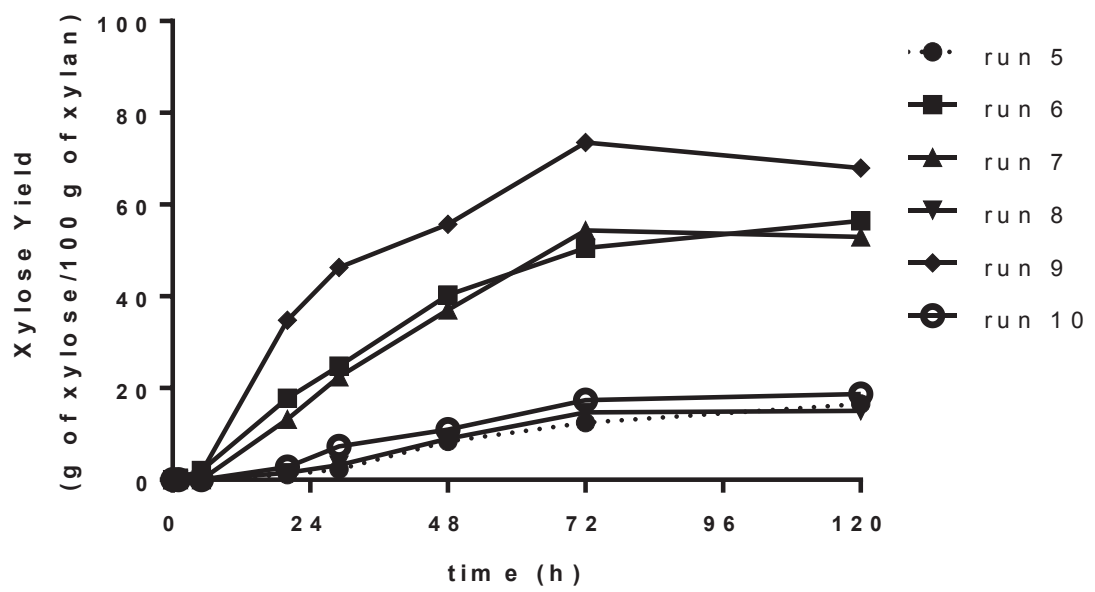

c)



Fig. 4. Simultaneous saccharification and fermentation of solubilized xylan in 20\% [Ch]Cl:U (1:1 M ratio) (operational conditions described in Table 3).

equation (3).

Table 5 lists the regression coefficients, their significance (based on the Students $t$-test), and the statistical parameters measuring the correlation $\left(\mathrm{R}^{2}\right)$ and the significance of model (based on the Fisheŕs F-test). Based on the results listed in Table 5, the most influential variables on SSF process for xylitol production were xylan concentration in $[\mathrm{Ch}] \mathrm{Cl}: \mathrm{U}$ aqueous solutions and enzyme loading. The variable xylan concentration in [Ch]Cl:U aqueous solutions had a negative effect in xylitol yield. This negative effect is due to the inhibitory effect of high concentrations of $[\mathrm{Ch}] \mathrm{Cl}: \mathrm{U}$ on enzymatic saccharification of xylan, as evaluated above.

Fig. 5a shows the effect of glucose concentration and xylan concentration in $[\mathrm{Ch}] \mathrm{Cl}: \mathrm{U}$ aqueous solution on xylitol production fixing the enzyme loading at $0.77 \mathrm{mg} / \mathrm{mL}$. As seen, maximal xylitol concentration 
fixed $\times 3=0.77 \mathrm{mg}$ protein $/ \mathrm{mL}$
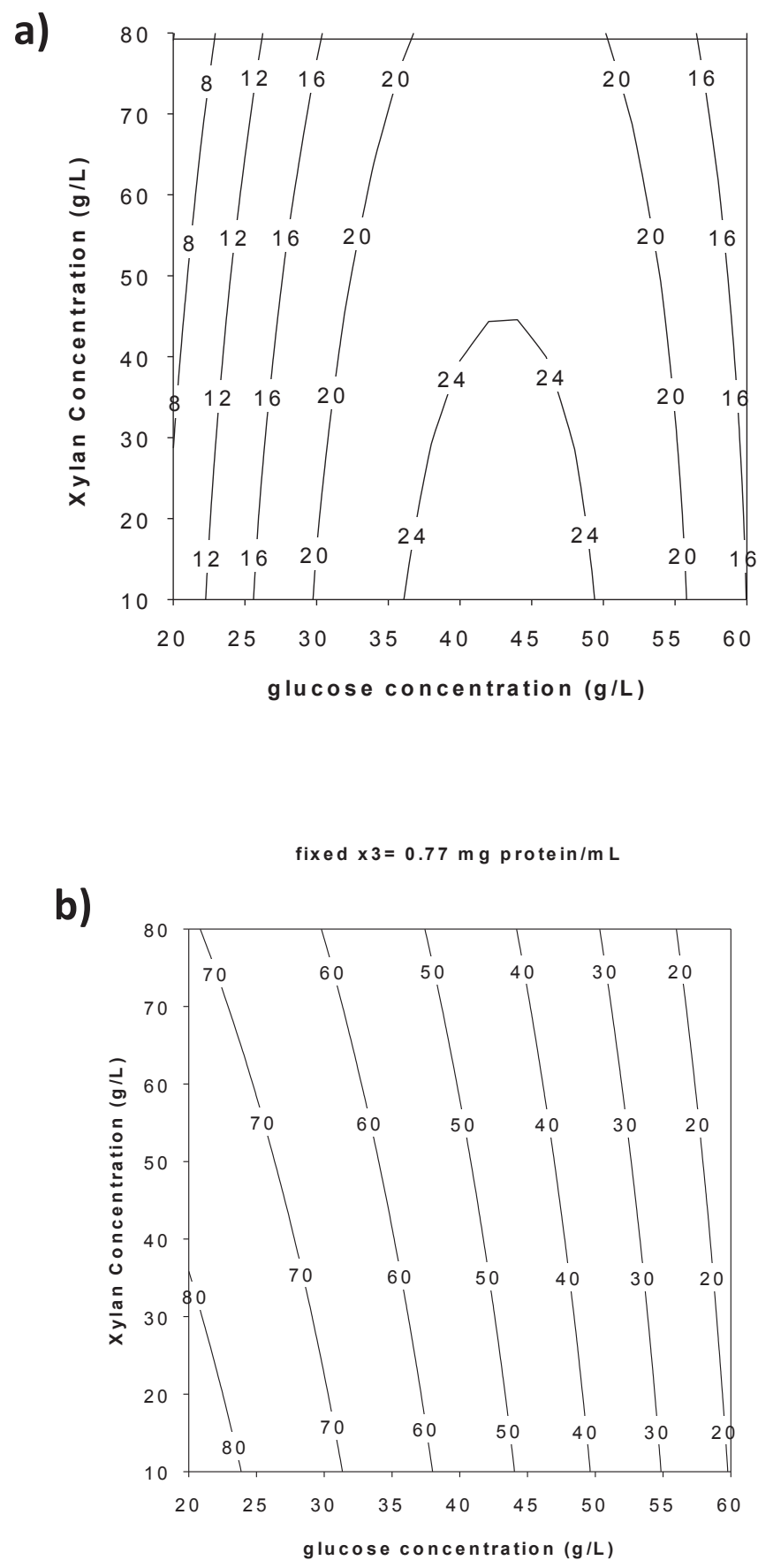

Fig. 5. Response surface of: a) Xylitol concentration $(\mathrm{g} / \mathrm{L})$ on glucose concentration $(\mathrm{g} / \mathrm{L})$ and xylan concentration in $[\mathrm{Ch}] \mathrm{Cl}: \mathrm{U}$ aqueous solutions; $\mathrm{b}$ ) Xylitol yield ( $\mathrm{g}$ of xylose/100 $\mathrm{g}$ of xylan) on glucose concentration and xylan concentration in DES aqueous solutions.

was obtained for the xylan concentration $<50 \mathrm{~g} / \mathrm{L}$ (corresponding to $10 \mathrm{wt} \%$ of $[\mathrm{Ch}] \mathrm{Cl}: \mathrm{U}$ in the fermentation medium) and glucose concentration ranged between 35 and $50 \mathrm{~g} / \mathrm{L}$. On the other hand, the decrease of xylan in [Ch]Cl:U, which corresponds to a decrease in DES concentration in the solution, as well as glucose concentration, improve the xylitol yield for the highest enzyme loading evaluated $(0.77 \mathrm{mg}$ / $\mathrm{mL}$ ) (Fig. 5b). The presence of [Ch]Cl:U reduces the enzymatic saccharification of xylan decreasing the substrate concentration (xylose) for the xylitol production. Moreover, the high glucose concentration in these processes causes a catabolite repression of xylose uptake (Baptista et al., 2018), presenting the maximum xylitol yield for $20 \mathrm{~g} / \mathrm{L}$ of glucose (lowest glucose concentration evaluated).

Aiming at optimizing the SSF process for xylitol production, the variables xylose concentration and yield were used as response variables for the multiple response optimization of the model. The following operational conditions maximize the concentration and yield of xylitol: glucose concentration of $20 \mathrm{~g} / \mathrm{L}, 36.25 \mathrm{~g} / \mathrm{L}$ of xylan in $7.25 \mathrm{wt} \%$ of ChCl:U and enzyme loading of $0.77 \mathrm{mg} / \mathrm{mL}$. The predicted xylitol concentration and yield were $23.67 \mathrm{~g} / \mathrm{L}$ and $64.83 \%$, respectively. To validate the model, an additional experiment was carried out under optimized conditions. The results for the validation experiment were $23.94 \mathrm{~g} / \mathrm{L}$ and $66.04 \%$ of xylitol yield, thus validating the model.

This study thus reveals that xylan in aqueous solutions of [Ch]Cl:U can be used directly for simultaneous saccharification and bioconversion into xylitol. The yields attained can be slightly hampered by high DES concentrations, but due to the outstanding capability of [Ch]Cl:U to dissolve xylan it is possible to attain good xylitol yields by simply diluting the concentrated solution. To our knowledge, this is the first work showing the use of $[\mathrm{Ch}] \mathrm{Cl}: \mathrm{U}$ solutions for the biological conversion of xylan into xylitol.

\section{Conclusions}

In this work, xylan solubilized in $[\mathrm{Ch}] \mathrm{Cl}: \mathrm{U}$ aqueous solutions at different molar ratios was used as subtrate for xylose production, showing a significant influence of selected molar ratio. Maximum xylose yield (81\%) was attained using molar ratio 1:1. The fermentation process was not affected by the presence of [Ch]Cl:U using an industrial $S$. cerevisiae strain. The xylitol production was optimized using xylan solubilized in $[\mathrm{Ch}] \mathrm{Cl}: \mathrm{U} 1: 1$ by SSF process, attaining a maximum xylitol yield of $66 \%$. The results obtained pave the way for the biological process route of xylitol production from biomass applying neoteric solvents such as DES.

\section{CRediT authorship contribution statement}

Aloia Romaní: Conceptualization, Writing - original draft, Validation. Eduarda S. Morais: Conceptualization, Writing - original draft, Validation. Pedro O. Soares: Writing - original draft, Validation. Mara G. Freire: Validation, Writing - review \& editing. Carmen S.R. Freire: Validation, Writing - review \& editing. Armando J.D. Silvestre: Conceptualization, Validation, Writing - review \& editing. Lucília Domingues: Conceptualization, Validation, Writing - review \& editing.

\section{Declaration of Competing Interest}

The authors declare that they have no known competing financial interests or personal relationships that could have appeared to influence the work reported in this paper.

\section{Acknowledgements}

This study was supported by BIOVINO project (0688_BIOVINO_6_E) funded by INTERREG España - Portugal and European Regional Development Fund (ERDF), carried out at the Biomass and Bioenergy Research Infrastructure (BBRI) - LISBOA-01-0145-FEDER-022059, supported by Operational Programme for Competitiveness and Internationalization (PORTUGAL2020), by Lisbon Portugal Regional Operational Programme (Lisboa 2020) and by North Portugal Regional Operational Programme (Norte 2020) under the Portugal 2020 Partnership Agreement, through the European Regional Development Fund (ERDF) and supported by the Portuguese Foundation for Science and Technology (FCT) under the scope of the strategic funding of UIDB/ 
Table 4

Main results obtained from Simultaneous Saccharification and Fermentation assays.

\begin{tabular}{|c|c|c|c|c|c|c|c|c|}
\hline & $\begin{array}{l}\text { Glucose }(\mathrm{g} / \mathrm{L}) \text { at } \\
20 \mathrm{~h}\end{array}$ & $\begin{array}{l}\text { EtOH Max }(g / \\
\text { L) }\end{array}$ & $\begin{array}{l}\text { EtOH }(\mathrm{g} / \mathrm{L}) \text { at } \\
120 \mathrm{~h}\end{array}$ & $\begin{array}{l}\text { Xylose Max (g/ } \\
\text { L) }\end{array}$ & $\begin{array}{l}\text { Xylose }(\mathrm{g} / \mathrm{L}) \text { at } \\
120 \mathrm{~h}\end{array}$ & $\begin{array}{l}\text { Xylitol (g/L) } \\
\left(\mathrm{y}_{1}\right)\end{array}$ & $\begin{array}{l}\text { Xylitol Yield (\%) } \\
\left(\mathrm{y}_{2}\right)\end{array}$ & $\begin{array}{l}\text { Xylitol Productivity Qp at } 48 \mathrm{~h}(\mathrm{~g} / \\
\text { Lh) }\left(\mathrm{y}_{3}\right)\end{array}$ \\
\hline run 1 & 9.9 & 15.3 & 0.0 & 5.8 & 0.0 & 6.5 & 64.96 & 0.121 \\
\hline run 2 & 0.1 & 28.4 & 8.1 & 5.2 & 0.0 & 7.62 & 76.15 & 0.138 \\
\hline run 3 & 1.2 & 22.0 & 8.0 & 9.6 & 0.0 & 19.51 & 43.35 & 0.224 \\
\hline run 4 & 8.9 & 17.6 & 8.1 & 12.6 & 8.9 & 24.53 & 54.52 & 0.348 \\
\hline run 5 & 32.9 & 15.2 & 9.3 & 18.1 & 16.1 & 13.23 & 16.54 & 0.14 \\
\hline run 6 & 0.0 & 7.8 & 0.0 & 10.8 & 0.0 & 25.4 & 56.44 & 0.377 \\
\hline run 7 & 2.1 & 14.2 & 0.0 & 9.0 & 0.0 & 23.83 & 52.95 & 0.348 \\
\hline run 8 & 6.7 & 9.6 & 0.0 & 20.2 & 19.8 & 12.01 & 15.01 & 0.15 \\
\hline run 9 & 0.2 & 3.1 & 0.0 & 5.7 & 0.0 & 6.8 & 68 & 0.116 \\
\hline run 10 & 1.2 & 13.1 & 4.2 & 17.1 & 16.8 & 14.96 & 18.69 & 0.183 \\
\hline run 11 & 27.5 & 3.9 & 2.6 & 20.7 & 19.3 & 4.62 & 5.77 & 0.024 \\
\hline run 12 & 1.9 & 7.8 & 0.0 & 10.0 & 0.0 & 6.55 & 65.53 & 0.127 \\
\hline run 13 & 0.0 & 2.8 & 0.0 & 7.0 & 0.0 & 15.72 & 34.93 & 0.298 \\
\hline run 14 & 7.4 & 4.9 & 0.0 & 10.7 & 0.0 & 18.71 & 41.57 & 0.222 \\
\hline run 15 & 34.1 & 7.5 & 3.3 & 12.3 & 3.5 & 16.64 & 36.97 & 0.175 \\
\hline
\end{tabular}

Table 5

Regression coefficients and statistical parameters measuring the correlation and significance of the models.

\begin{tabular}{llll}
\hline & \multicolumn{2}{l}{ Coefficients } & \\
\cline { 2 - 4 } & $\mathrm{y}_{1}:[$ Xylitol] & $\mathrm{y}_{2}:$ Xylitol Yield & $\mathrm{y}_{3}:$ Qp48 (productivity) \\
\hline $\mathrm{b}_{0 \mathrm{j}}$ & 23.58 & 52.41 & 0.320 \\
$\mathrm{~b}_{1 \mathrm{j}}$ & -0.51 & -1.79 & -0.039 \\
$\mathrm{~b}_{2 \mathrm{j}}$ & $1.95^{\mathrm{a}}$ & $-30.47^{\mathrm{a}}$ & -0.002 \\
$\mathrm{~b}_{3 \mathrm{j}}$ & $2.22^{\mathrm{a}}$ & $5.10^{\mathrm{a}}$ & 0.028 \\
$\mathrm{~b}_{11 \mathrm{j}}$ & -0.57 & -0.46 & -0.009 \\
$\mathrm{~b}_{22 \mathrm{j}}$ & -12.77 & $-4.67^{\mathrm{b}}$ & $-0.170^{\mathrm{c}}$ \\
$\mathrm{b}_{33 \mathrm{j}}$ & $-2.11^{\mathrm{b}}$ & $-5.48^{\mathrm{b}}$ & -0.020 \\
$\mathrm{~b}_{12 \mathrm{j}}$ & 0.43 & 1.69 & -0.002 \\
$\mathrm{~b}_{13 \mathrm{j}}$ & $-1.55^{\mathrm{c}}$ & $-3.44^{\mathrm{c}}$ & -0.009 \\
$\mathrm{~b}_{23 \mathrm{j}}$ & $2.02^{\mathrm{b}}$ & -0.42 & 0.040 \\
$\mathrm{~F}$ & 42.00 & 115.46 & 3.528 \\
Significance & $>99$ & $>99$ & $>90$ \\
$\mathrm{R}^{2}$ & 0.987 & 0.995 & 0.864 \\
\hline
\end{tabular}

${ }^{\text {a }}$ Coefficients significant at the $99 \%$ confidence level.

b Coefficients significant at the $95 \%$ confidence level.

c Coefficients significant at the $90 \%$ confidence level.

04469/2020 unit, BioTecNorte operation (NORTE-01-0145-FEDER000004) funded by the European Regional Development Fund under the scope of Norte2020 - Programa Operacional Regional do Norte and within the scope of the project CICECO-Aveiro Institute of Materials, UIDB/50011/2020 \& UIDP/50011/2020, financed by national funds through the FCT/MCTES. The research leading to reported results has received funding from FCT through the projects DeepBiorefinery (PTDC/AGR-TEC/1191/2014) and MultiBiorefinery (POCI-01-0145FEDER-016403), EcoTech project (POCI-01-0145-FEDER-032206), through C. Freire Researcher contract (CEECIND/00464/2017) and E. S. Morais PhD grant (SFRH/BD/129341/2017).

\section{References}

Abbott, A.P., Capper, G., Davies, D.L., Rasheed, R.K., Tambyrajah, V., 2003. Novel solvent properties of choline chloride/urea mixtures. Chem. Commun. 70-71.

Alvarez-Vasco, C., Ma, R., Quintero, M., Guo, M., Geleynse, S., Ramasamy, K.K., Wolcott, M., Zhang, X., 2016. Unique low-molecular-weight lignin with high purity extracted from wood by deep eutectic solvents (DES): a source of lignin for valorization. Green Chem. 18, 5133-5141. https://doi.org/10.1039/c6gc01007e.

Assembly, U.N.G., 2015. Transforming our world: the 2030 Agenda for Sustainable Development.

Attri, P., Venkatesu, P., Kumar, A., Byrne, N., 2011. A protic ionic liquid attenuates the deleterious actions of urea on $\alpha$-chymotrypsin. Phys. Chem. Chem. Phys. 13, 17023-17026. https://doi.org/10.1039/c1cp22195g.

Bailey, M.J., Biely, P., Poutanen, K., 1992. Interlaboratory testing of methods for assay of xylanase activity. J. Biotechnol. 23, 257-270. https://doi.org/10.1016/01681656(92)90074-J.
Baptista, S.L., Cunha, J.T., Romaní, A., Domingues, L., 2018. Xylitol production from lignocellulosic whole slurry corn cob by engineered industrial Saccharomyces cerevisiae PE-2. Bioresour. Technol. 267, 481-491. doi:10.1016/j.biortech.2018.07.068.

Baptista, S.L., Romaní, A., Domingues, L. 2020. Chapter: Biotechnological advancements, innovations and challenges for sustainable xylitol production by yeast in Book: Biotechnological advancements, innovations and challenges for sustainable xylitol production by yeast, Encyclopedia of Mycology, Ed. Elsevier (Accepted).

Bradford, M., 1976. A rapid and sensitive method for the quantification of microgram quantities of protein utilizing the principle of protein-dye binding. Anal. Biochem. 72, 248-254. https://doi.org/10.1016/0003-2697(76)90527-3.

Budzianowski, W.M., 2017. High-value low-volume bioproducts coupled to bioenergies with potential to enhance business development of sustainable biorefineries. Renew. Sustain. Energy Rev. 70, 793-804. https://doi.org/10.1016/j.rser.2016.11.260.

Clark, J.H., 2007. Green chemistry for the second generation biorefinery - sustainable chemical manufacturing based on biomass. Green Chem. 609, 603-609. https://doi. org/10.1002/jctb.

Clarke, Coby J, Tu, W., Levers, O., Bro, A., Hallett, J.P., 2018. Green and sustainable solvents in chemical processes. Chem. Rev. 118, 747-800. https://doi.org/10.1021/ acs.chemrev.7b00571.

Costa, C.E., Romaní, A., Cunha, J.T., Johansson, B., Domingues, L., 2017. Integrated approach for selecting efficient Saccharomyces cerevisiae for industrial lignocellulosic fermentations: Importance of yeast chassis linked to process conditions. Bioresour. Technol. 227, 24-34. https://doi.org/10.1016/j.biortech.2016.12.016.

Cunha, J.T., Romaní, A., Costa, C.E., Sá-Correia, I., Domingues, L., 2019. Molecular and physiological basis of Saccharomyces cerevisiae tolerance to adverse lignocellulosebased process conditions. Appl. Microbiol. Biotechnol. 103, 159-175. https://doi. org /10.1007/s00253-018-9478-3.

Domínguez, E., Romaní, A., Domingues, L., Garrote, G., 2017. Evaluation of strategies for second generation bioethanol production from fast growing biomass Paulownia within a biorefinery scheme. Appl. Energy 187, 777-789. https://doi.org/10.1016/j. apenergy.2016.11.114.

Durand, E., Lecomte, J., Baréa, B., Villeneuve, P., 2014. Towards a better understanding of how to improve lipase-catalyzed reactions using deep eutectic solvents based on choline chloride. Eur. J. Lipid Sci. Technol. 116, 16-23. https://doi.org/10.1002/ejlt. 201300246.

Gullón, B., Muñiz-Mouro, A., Lú-Chau, T.A., Moreira, M.T., Lema, J.M., Eibes, G., 2019. Green approaches for the extraction of antioxidants from eucalyptus leaves. Ind. Crops Prod. 138, 111473. https://doi.org/10.1016/j.indcrop. 2019.111473.

Gunny, A.A.N., Arbain, D., Nashef, E.M., Jamal, P., 2015. Applicability evaluation of deep eutectic solvents-cellulase system for lignocellulose hydrolysis. Bioresour. Technol. 181, 297-302. https://doi.org/10.1016/j.biortech.2015.01.057.

Guo, Z., Ling, Z., Wang, C., Zhang, X., Xu, F., 2018. Integration of facile deep eutectic solvents pretreatment for enhanced enzymatic hydrolysis and lignin valorization from industrial xylose residue. Bioresour. Technol. 265, 334-339. https://doi.org/10. 1016/j.biortech.2018.06.027.

Kumar, P., Barrett, D.M., Delwiche, M.J., Stroeve, P., 2009. Methods for pretreatment of lignocellulosic biomass for efficient hydrolysis and biofuel production. Ind. Eng. Chem. Res. 48, 3713-3729.

Latif, F., Rajoka, M.I., 2001. Production of ethanol and xylitol from corn cobs by yeasts. Bioresour. Technol. 77, 57-63. https://doi.org/10.1016/S0960-8524(00)00134-6.

Loow, Y.L., New, E.K., Yang, G.H., Ang, L.Y., Foo, L.Y.W., Wu, T.Y., 2017. Potential use of deep eutectic solvents to facilitate lignocellulosic biomass utilization and conversion. Cellulose 24, 3591-3618. https://doi.org/10.1007/s10570-017-1358-y.

Morais, E.S., Freire, M.G., Freire, C.S.R., Coutinho, J.A.P., Silvestre, A., 2020. Enhanced conversion of xylan into furfural using acidic deep eutectic solvents with dual solvent and catalyst behavior. ChemSusChem 1-8. https://doi.org/10.1002/cssc.201902848.

Morais, E.S., Mendonça, P.V., Coelho, J.F.J., Freire, M.G., Freire, C.S.R., Coutinho, J.A.P., Silvestre, A.J.D., 2018. Deep eutectic solvent aqueous solutions as efficient media for the solubilization of hardwood xylans. ChemSusChem 11, 753-762. https://doi.org/ 10.1002/cssc. 201702007.

Pereira, F.B., Romaní, A., Ruiz, H.A., Teixeira, J.A., Domingues, L., 2014. Industrial 
robust yeast isolates with great potential for fermentation of lignocellulosic biomass. Bioresour. Technol. 161, 192-199. https://doi.org/10.1016/j.biortech.2014.03.043.

Procentese, A., Johnson, E., Orr, V., Garruto Campanile, A., Wood, J.A., Marzocchella, A., Rehmann, L., 2015. Deep eutectic solvent pretreatment and subsequent saccharification of corncob. Bioresour. Technol. 192, 31-36. https://doi.org/10.1016/j. biortech.2015.05.053.

Romaní, A., Garrote, G., Alonso, J.L., Parajó, J.C., 2010. Bioethanol production from hydrothermally pretreated Eucalyptus globulus wood. Bioresour. Technol. 101, 8706-8712. https://doi.org/10.1016/j.biortech.2010.06.093.

Romaní, A., Larramendi, A., Yáñez, R., Cancela, Á., Sánchez, Á., Teixeira, J.A. Domingues, L., 2019. Valorization of Eucalyptus nitens bark by organosolv pretreatment for the production of advanced biofuels. Ind. Crops Prod. 132, 327-335. https://doi.org/10.1016/j.indcrop.2019.02.040.

Satlewal, A., Agrawal, R., Bhagia, S., Sangoro, J., Ragauskas, A.J., 2018. Natural deep eutectic solvents for lignocellulosic biomass pretreatment: recent developments, challenges and novel opportunities. Biotechnol. Adv. 36, 2032-2050. https://doi. org/10.1016/j.biotechadv.2018.08.009.

Shen, X.-J., When, J.-L., Mei, Q.-Q., Chen, X., Sun, D., Yuan, T.-Q., Sun, R.-C., 2019. Facile fractionation of lignocelluloses by biomass-derived deep eutectic solvent (DES) pretreatment for cellulose enzymatic hydrolysis and lignin valorization. Green Chem. 21, 275-283. https://doi.org/10.1039/c8gc03064b.

Soares, B., Tavares, D.J.P., Amaral, J.L., Silvestre, A.J.D., Freire, C.S.R., Coutinho, J.A.P.,
2017. Enhanced solubility of lignin monomeric model compounds and technical lignins in aqueous solutions of deep eutectic solvents. ACS Sustain. Chem. Eng. 5, 4056-4065. https://doi.org/10.1021/acssuschemeng.7b00053.

Soh, L., Eckelman, M.J., 2016. Green solvents in biomass processing. ACS Sustain. Chem. Eng. 4, 5821-5837. https://doi.org/10.1021/acssuschemeng.6b01635.

Werpy, T., Petersen, G., Aden, A., Bozel, J., Holladay, J., White, J., Manheim, A., 2004 Top Value Added Chemicals from Biomass Volume I - Results of Screening for Potential Candidates from Sugars and Synthesis Gas Top Value Added Chemicals.

Xu, F., Sun, J., Wehrs, M., Kim, K.H., Rau, S.S., Chan, A.M., Simmons, B.A., Mukhopadhyay, A., Singh, S., 2018. Biocompatible choline-based deep eutectic solvents enable one-pot production of cellulosic ethanol. ACS Sustain. Chem. Eng. 6, 8914-8919. https://doi.org/10.1021/acssuschemeng.8b01271.

Yemis, O., Mazza, G., 2011. Acid-catalyzed conversion of xylose, xylan and straw into furfural by microwave-assisted reaction. Bioresour. Technol. 102, 7371-7378. https://doi.org/10.1016/j.biortech.2011.04.050.

Zhang, Q., De Oliveira Vigier, K., Royer, S., Jérôme, F., 2012. Deep eutectic solvents: syntheses, properties and applications. Chem. Soc. Rev. 41, 7108-7146. https://doi. org/10.1039/c2cs35178a.

Zhang, L., Yu, Han, Yu, Hong-bing, Chen, Z., Yang, L., 2014. Conversion of xylose and xylan into furfural in biorenewable choline chloride - oxalic acid deep eutectic solvent with the addition of metal chloride. Chinese Chem. Lett. 25, 1132-1136. 